\title{
ANALISISIS SUASANA TOKO, LOKASI, DAN MEDIA SOSIAL PENGARUHNYA TERHADAP KEPUTUSAN PEMBELIAN KONSUMEN DI KOPI AENK
}

\author{
1Popo Suryana Neng, ${ }^{2}$ Tanti Tresnawati \\ popo_suryana@unpas.ac.id. \\ ${ }^{1,2}$ Fakultas Ekonomi dan Bisnis Universitas Pasundan
}

\begin{abstract}
This study aims to determine how much the effect of store atmospher, location and social media on purchasing decisons on Kopi Aenk both partially or simultaneously. The research method used is descriptive and verifikatif with total sample of 91 respondents. Data collection techniques used is observation, interview and questionnaires. The data analysis method used is validity test analysis, reliability test, multiple linear regression, multiple correlation coefficient, hypothesis testing, and determination coefficient. The results of this study indicate that the store atmosphere variable, location variable, social media variable, and purchase decision variable in the lessagree category. The based on the results of the calculation of the coefficient of determination partially store atmosphere that has a greater effect on purchasing decisions that is equal to 42,7\%, while location has an effect on purchasing decisions which equal $24,6 \%$, and social media has an effect on purchasing decisions which equal $22,2 \%$. So, the influence of store atmosphere, location, and social mediaon purchasing decisions which equal $89,5 \%$.
\end{abstract}

Keywords: Store Atmosphere, Location, Social Media, and Purchasing Decisions

\begin{abstract}
ABSTRAK
Penelitian ini bertujuan untuk mengetahui seberapa besar pengaruh suasana toko, lokasi, dan media sosial terhadap keputusan pembelian konsumen di Kopi Aenk baik secara parsial maupun simultan. Metode penelitian yang digunakan adalah deskriptif dan verifikatif dengan jumlah sampel 91 responden. Teknik pengumpulan data yang digunakan adalah observasi, wawancara, dan menyebarkan kuesioner. Metode analisis data yang digunakan adalah analisis uji validitas, analisis reliablitas, analisis regresi linier berganda, korelasi berganda, uji hipotesis, dan koefisien determinasi. Hasil penelitan ini menunjukan bahwa variabel suasana toko, lokasi, media sosial dan keputusan pembelian berada pada kategori kurang setuju. Secara parsial variabel suasana toko lebih besar pengaruhnya terhadap keputusan pembelian yaitu sebesar $42,7 \%$, sedangkan varabel lokasi pengaruhya terhadap keputusan pembelian yaitu sebesar $24,6 \%$, dan variabel media sosial pengaruhnya terhadap keputusan pembelian yaitu sebesar $22,2 \%$. Sehingga didapatkan pengaruh suasana toko, lokasi, dan media sosial terhadap keputusan pembelian sebesar $89,5 \%$.
\end{abstract}

Kata Kunci: Suasana Toko, Lokasi, Media Sosial, dan Keputusan Pembelian

\section{PENDAHULUAN}

Perkembangan dunia bisnis di Indonesia semakin hari semakin mengalami kemajuan yang lebih baik, itu disebabkan oleh perubahan pola pikir manusia yang dinamis serta perubahan teknologi yang semakin canggih. Persaingan yang semakin kompetetif, memicu pelaku bisnis berusaha untuk merebut posisi pangsa pasar melalui berbagai inovasi yang disajikan dalam bentuk produk maupun jasa yang ditawarkan serta mengembangkan agar dapat menguasai market share. Setiap pelaku bisnis dituntut untuk memiliki kesadaran dan kepekaan terhadap kebutuhan serta keinginan dari konsumen. Tidak terkecuali usaha dalam penyajian makanan dan minuman (food service) yang dimulai dari skala kecil seperti warung- 
warung dan cafe tenda, bisnis makanan berskala menengah seperti depot, rumah makan dan cafe, sampai dengan bisnis makanan yang berskala besar seperti restoran-restoran di hotel berbintang.

Bisnis kuliner yang meliputi usaha jasa makanan dan minuman diatur dalam Peraturan Daerah Kota Bandung Nomor 7 Tahun 2012 tentang penyelenggaraan kepariwisataan. Peraturan tersebut tertuang dalam pasal 18 yang restoran dan cafe merupakan usaha jasa dari makanan dan minuman hal ini dijelaskan pada UU 10/2009 disebutkan "bahwa yang dimaksud dengan usaha jasa makanan minuman adalah usaha jasa penyediaan makanan dan minuman yang dilengkapi dengan peralatan dan perlengkapan untuk proses pembuatan dapat berupa restoran, cafe, jasa boga, dan bar/kedai minum" peraturan Menteri Kebudayaan dan Parawisata Nomor PM.87/HK.501/MKP2010 tentang tata cara pendaftaran usaha jasa makanan dan minuman, memberikan defenisi bahwa restoran dan cafe adalah usaha penyedia makanan dan minuman dilengkapi dengan peralatan dan perlengkapan untuk proses pembuatan, penyimpanan dan penyajiannya. Dimana cafe dan restoran harus berada didalam suatu tempat atau lokasi yang tidak berpindah-pindah.

Banyaknya cafe dengan berbagai konsep dan ide-ide yang ditawarkan hal ini mengakibatkan persaingan usaha cafe di kota Bandung meningkat. Perusahaan-perusahaan menonjolkan ciri khas dan terus berinovasi serta membuat ide-ide baru yang kreatif agar dapat lebih unggul dari perusahaan lain yang menawarkan produk sejenis dan harga yang hampir sama sehingga tentunya diharapkan dapat menarik perhatian konsumen. Berikut pada Tabel 1.1 peneliti sajikan data jumlah cafe dan restoran yang ada di kota Bandung dalam jangka lima tahun terakhir:

Tabel 1.1

Jumlah Cafe di Kota Bandung

\begin{tabular}{cc}
\hline Tahun & Jumlah Cafe \\
\hline 2014 & 258 \\
2015 & 270 \\
2016 & 330 \\
2017 & 420 \\
2018 & 510 \\
\hline
\end{tabular}

Sumber: Dinas Pariwisata Kota Bandung

Perkembangan teknologi dan informasi di dunia khususnya internet mengalami perkembangan dengan sangat pesat. Internet menghubungkan satu orang dengan yang lainnya, menyediakan informasi, sebagai sarana hiburan, maupun sebagai sarana komunikasi. Hal ini menjadikan internet saat ini telah menjadi kebutuhan pokok bagi sebagian besar orang selain kebutuhan pangan, dan papan. Beberapa alasan mengapa internet begitu banyak di gemari antara lain: kecepatan informasi, membantu di berbagai bidang dikehidupan, dan fleksibilitas. Setiap tahun pengguna jasa internet terus meningkat hal ini dapat dilihat pada gambar 1.1, sebagai berikut : 


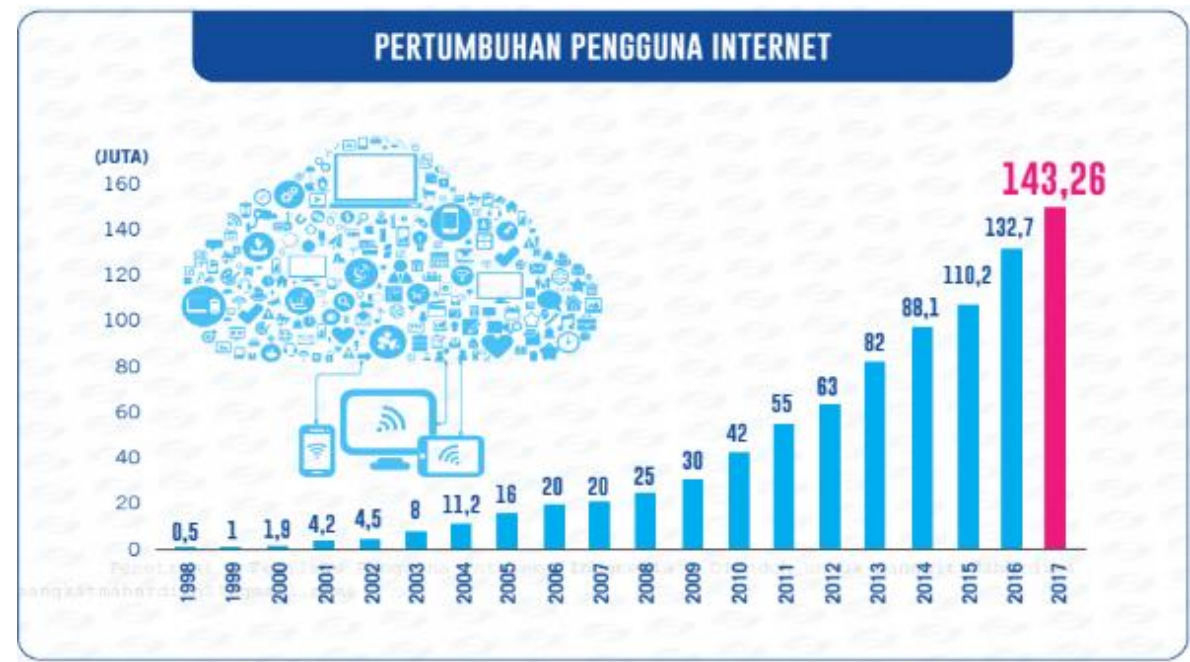

Gambar 1.1

Pertumbuhan Pengguna Internet di Indonesia

Sumber : Asosiasi Penyelenggara Jasa Internet Indonesia

Fenomena ini tentu saja menjadi peluang bisnis baru bagi beberapa pihak, tidak terkecuali para pelaku bisnis cafe. Kemudian para pelaku bisnis cafe harus dapat mendapatkan peluang yang ada agar peluang tersebut menghasilkan manfaat yang baik bagi perusahaan. Seiring dengan berkembangnya teknologi internet pada saat ini, masyarakat tidak akan kesulitan untuk mencari cafe-cafe yang ada karena saat ini untuk mencari informasi yang dibutuhkannya sangatlah mudah. Salah satu informasi di internet yang mudah didapat oleh masyarakat adalah rating penilaian cafe favorit untuk rekomendasi dikunjungi. Berikut ini adalah penilaian pelanggan dari beberapa cafe yang ada di Kota Bandung yaitu :

Tabel 1.2

\begin{tabular}{ccc} 
Penilaian Pelanggan untuk Rekomendasi & Tempat Favorit \\
\cline { 2 - 3 } No & \multicolumn{1}{c}{ Nama Cafe } & Rating \\
\hline 1 & Kedai Kopi Euy & 4,4 \\
2 & Kopi Eyang & 4,4 \\
3 & Kopi Senja & 4,3 \\
4 & Kedai Kopi Kamu & 4,3 \\
5 & Kopi Kelenteng & 4,2 \\
6 & Kopi Tarik Ulur & 4,20 \\
7 & Dreezel Coffee & 4,17 \\
8 & Kedai Kopi Bara & 4,10 \\
9 & Roemah Kopi & 4,0 \\
10 & Titik Kopi & 4,0 \\
11 & Warung Kopi Imah Babaturan & 3,96 \\
12 & Kopi Toko Djawa & 3,97 \\
13 & Kopi Cepot & 3,90 \\
14 & Aditi Coffee House and Space & 3,87 \\
15 & Kopi Aenk & 3,8 \\
\hline
\end{tabular}

Sumber: Pergikuliner.com

Berdasarkan data yang disajikan di atas menunjukan bahwa rating dari penilaian pelanggan untuk rekomendasi tempat setelah pelanggan pernah berkunjng ke salah satu cafe tertentu. Rata-rata rating cafe yang berada di kota Bandung mendapat rating 4 sedangkan untuk Kopi Aenk mendapatkan raing 3,8 menandakan bahwa pelanggan yang telah berkunjung kurang puas, maka dari itu peneliti memutuskan untuk memilih Kopi Aenk sebagai lokasi penelitian. 
Kopi Aenk merupakan tempat yang di desain dengan konsep rumahan dan juga menyediakan menu produk yang beragam dengan ciri khas nya yaitu kopi dengan berbagai varians beans serta disajikan dengan berbagai metode penyajian. Pertumbuhan cafe yang pesat saat ini menimbulkan persaing pada bisnis ini semakin kompetitif dan dituntut harus sekreatif mungkin untuk mengkonsep cafe itu sendiri. Suasana toko bisa menjadi alternatif untuk membedakan cafe yang satu dengan yang lainnya. Perbedaan diperlukan karena dari setiap bisnis pasti didapati produk yang serupa dengan harga yang berkisar beda tipis bahkan sama. Suasana toko bisa menjadi alasan lebih bagi konsumen untuk tertarik dan memilih dimana ia akan berkunjung dan membeli.

Suasana toko yang menarik perlu didukung oleh lokasi yang strategis bertujuan agar toko dapat dijangkau dengan mudah oleh konsumen. Faktor-faktor yang penting dipertimbangkan dalam pemilihan lokasi harus dapat membuat konsumen dapat dengan mudah menjangkau lokasi tersebut, bagi suatu toko faktor yang paling penting yaitu mudah dijangkau oleh konsumen dan memiliki akses jalan yang mudah ditemukan dan juga lokasi yang banyak dilewati orang banyak sebagai target pasar sasaran. Dalam proses penentuan dimana seseorang akan berkunjung ke cafe bahwa faktor lokasi akan ikut menentukan, yang berarti lokasi yang strategis akan membuat konsumen menjadi tertarik dan berminat untuk berkunjung ke cafe yang akhirnya akan melakukan pembelian.

Banyaknya cafe yang berada di Kota Bandung, membuat perusahaan semakin dituntut untuk berinovasi dan semakin cepat dalam hal menarik konsumen. Menarik konsumen tidak hanya untuk menunjukan eksistensi dari perusahaan, tetapi juga untuk meningkatkan penjualan pada perusahaan tersebut, dan untuk mencapai target penjualan yang telah di tetapkan oleh perusahaan pada setiap bulannya. Peneliti menyimpulkan meneliti di Kopi Aenk berdasarkan data penjualan selama tujuh bulan terakhir.

Penjualan dari Kopi Aenk selama bulan terakhir yaitu dari Bulan Juli 2018 sampai dengan bulan Januari 2019 terdapat penurunan penjualan. Hal ini tentunya menjadi suatu ancaman untuk keberlangsungan bisnis dari Kopi Aenk dan juga menjelaskan bahwa Kopi Aenek mengalami permasalahan dalam keputusan pembelian konsumen.

Untuk mengetahui faktor apa yang menyebabkan keputusan pembelian yang rendah dan berdampak pada penurunan penjualan di Kopi Aenk. Maka peneliti melakukan penelitian pendahuluan dengan mengajukan kuisioner pertanyaan dengan indikator bauran pemasaran kepada 30 orang responden. Hasilnya survey yang sudah dilakukan dan diolah mendapatkan hasil permasalahan mengacu pada suasana toko, lokasi, dan media sosial.

Hasil prasurvey pada bauran pemasaran bukti fisik didapatkan hasil mayoritas responden sebanyak 26 orang menjawab cenderung tidak setuju $(86,7 \%)$ untuk pernyataan Kopi Aenk memiliki tempat parkir yang luas dan memadai, untuk pernyataan suasana toko Kopi Aenk tenang dan nyaman mayoritas konsumen sebanyak 26 orang menyatakan cenderung tidak setuju (86\%) dari 30 orang, dan pada pernyataan fasilitas yang disediakan sangat nyaman untuk konsumen mayoritas konsumen menjawab cenderung tidak setuju sebanyak 24 orang atau $80 \%$.

Hasil prasurvey pada bauran pemasaran tempat didapatkan hasil untuk pernyataan lokasi Kopi Aenk sangat mudah dijangka dengan transportasi umum dari 30 konsumen menghasilkan bahwa mayoritas konsumen sebanyak 26 orang atau $86 \%$ menyatakan cenderung tidak setuju, adapun pada penyataan letak Kopi Aenk dapat dilihat dengan sangat jelas dari sisi jalan mayoritas konsumen sebanyak 25 orang atau $82 \%$ menyatakan cenderung tidak setuju, dan pada penyataan terakhir untuk bauran pemasaran tempat mayoritas konsumen menyatakan cenderung tidak setuju sebanyak 24 orang atau $80 \%$ pada pernyataan lokasi Kopi Aenk mudah ditemukan.

Hasil prasurvey pada bauran pemasaran promosi didapatkan hasil mayoritas responden sebanyak 26 orang (80\%) cenderung tidak pada pernyataan penyampaian Informasi produk melalui media sosial yang di berikan mudah di pahami sehingga saya memilih Kopi Aenk. pada pernyataan saya sering melihat promosi melalui media sosial yang di lakukan Kopi Aenk rata-rata konsumen sebanyak 24 orang $(79,9 \%)$ menyatakan cenderung tidak setuju dari 30 konsumen, sedangkan untuk pernyataan Kopi Aenk melakukan promosi dengan cara 
membagikan brosur, mayoritas konsumen sebanyak 17 orang atau $56 \%$ menyatakan cenderung setuju. Dari hasil ini disimpulkan bahwa pada bauran pemasaran promosi terdapat suatu masalah khususnya promosi yang dilakukan melalui media sosial.

Sehingga dapat disimpulkan bahwa suasana toko di kopi Aenk masih kurang nyaman bagi konsumen, lokasi dari toko yang tidak cukup mudah ditemukan dan dijangkau oleh konsumen dengan transportasi umum, dan promosi yang di berikan melalui media sosial yang digunakan kurang menarik minat bagi konsumen dan penyampain informasi produk melalui media sosial pun kurang di pahami oleh konsumen. Hal ini menunjukan bahwa suasana toko, lokasi, dan media sosial yang menyebabkan keputusan pembelian konsumen di Kopi Aenk kurang baik, karena konsumen memutuskan tidak melakukan pembelian produk di Kopi Aenk, berdampak pada menurunnya pendapatan Kopi Aenk, oleh karena itu peneliti tertarik untuk melakukan penelitian lebih dalam di Kopi Aenk.

Suasana toko yang nyaman, lokasi yang strategis, dan promosi melalui media sosial yang mudah dipahami konsumen harus diperhatikan perusahaan jika ingin produk atau jasa yang dipasarkan dapat menarik perhatian konsumen, karena suasana toko yang nyaman, lokasi yang mudah dijangkau dan mudah diakses, serta promosi media sosial yang mudah dipahami oleh konsumen dapat mempengaruhi keputusan pembelian. Hal tersebut dibuktikan oleh penelitian yang dilakukan oleh Anggun, Zuhrufanina, Ika dan Yoga (2017) yang menunujukan hasil penelitian bahwa variabel suasana toko, variabel lokasi, dan variabel media sosial memiliki pengaruh yang positif dan signifikan terhadap variabel keputusan pembelian.

\section{KAJIAN PUSTAKA}

\section{Suasana Toko}

Kotler dan Keller (2016:561) menyatakan bahwa "Every store has a look and a phsycal layout that makes it hard or easy to move around". Perencanaan suasana toko yang baik, perusahaan dapat meningkatan pengalaman yang dirasakan oleh konsumen yang nantinya dapat mempengaruhi pembelian. Maka dari itu, pihak manajemen perlu memperhatikan dan mempertimbangkan suasana toko jika ingin menarik, memikat, atau mendorong konsumen untuk datang ke toko untuk melakukan pembelian lalu kembali lagi ke toko dan akhirnya melakukan pembelian berikutnya. . Suasana toko bertujuan untuk memberikan kenyamanan kepada pelanggan dan dapat menjadi daya tarik tersendiri bagi pelanggan agar tertarik untuk datang ketoko, melakukan pembelian dan menjadi konsumen yang setia bagi perusahaan.

Definisi suasana toko dikemukakan oleh Levy dan Weitz dalam jurnal Chindy Juwita Dessyana (2013:846) menyatakan bahwa: Suasana toko adalah penciptaan suasana toko melalui visual, penataan, cahaya, musik, dan aroma yang dapat menciptakan lingkungan pembelian yang nyaman sehingga dapat mempengaruhi persepsi dan emosi konsumen untuk melakukan pembelian.

Menurut Levy \& Weitz (2014:434) "Store atmosphere reflects the combination of store physical caracteristics, such as it architecture, layout, sign and display, colour, lighting, temperature, sound and smells, which together create and image in the customers mind". Adapun pendapat lainnya mengenai definisi dari suasana toko, yang dikemukakan oleh Berman dan Evan yang dialih bahasakan oleh Lina Salim (2014:528) menyatakan bahwa: "Suasana toko meliputi berbagai tampilan interior, eksterior, tata letak, lalu lintas internal toko, kenyamanan, udara, layanan, musik, seragam, pajangan barang dan sebagainya yang menimbulkan daya tarik bagi konsumen dan membangkitkan keinginan untuk membeli."

Teori lainnya yang dikemukakan oleh Kotler dan Amstrong (2018:402) yang mengemukakan bahwa: "Store atmosphere is another importaint element in reseller's product arsenal. Retailer want create a unique store experience, one that suits the target market and moves costumer to buy".

Berdasarkan beberapa definisi yang dikemukakan para ahli di atas, maka peneliti sampai pada pemahaman bahwa suasana toko adalah perencanaan yang ditawarkan kepada konsumen sesuai dengan target pasarnya, yang dilakukan untuk menghasilkan efek 
emosional sehingga dapat menarik minat konsumen untuk berkunjung ke toko dan melakukan pembelian terhadap produk yang ditawarkan.

Dimensi suasana toko menurut Berman dan Evan yang dialih bahasakan oleh Lina Salim (2014:545) dapat diketahui berdasarkan elemen-elemen susasana toko:

1. Eksteriror (Bagian Luar Toko)

Eksterior (bagian luar toko) adalah bagian depan toko mencerminkan kemantapan dan kekokohan spirit perusahaan dan sifat kegiatan yang ada di dalamnya, serta dapat menciptakan kepercayaan dan goodwell bagi konsumen, yang termasuk dalam bagian elemen-elemen eksterior adalah sebagai berikut:

a. Store fornt (bagian muka toko)

b. Marquee (papan nama)

c. Exterance (pintu masuk)

d. Display window (tampilan jelndela)

e. Height and size (tinggi dan ukuran bangunan)

f. Uniqueness (keunikan)

g. Surrounding store (lingkungan sekitar)

h. Parking (tempat parkir)

2. General interior (Bagian dalam Toko)

General interior dari suatu toko harus dirancang untuk memaksimalkan visual merchandising. Seperti diketahui, iklan dapat menarik pembeli untuk datang ke toko, tapi yang paling utama yang dapat membuat penjualan setelah pembelian berada di toko adalah display. Display yang baik adalah yang dapat menarik perhatian para konsumen dan membantu mereka agar mudah mengamati, memeriksa dan memilih barang-barang dan akhirnya melakukan pembelian ketika konsumen masuk ke dalam toko. Kesan general interior ini dapat diciptakan melalui elemen-elemen general interior yaitu:

a. Flooring (lantai)

b. Colour and lighting (warna dan pencahayaan)

c. Future (penempatan)

d. Temperature (suhu udara)

e. Weidth of asles (lebar gang)

f. Dead areas

g. Personel (pramusaji)

h. Marchandise

i. Cash refister (kasir)

j. Technology modernization (moderenisasi teknologi)

k. Cleanliness (kebersihan)

3. Store layout (tata letak)

Store layout (tata letak) merupakan rencana untuk menentukan lokasi tertentu dan pengaturan dari jalan atau gang dalam toko yang cukup lebar dan dapat memudahkan para konsumen untuk berlalu-lalang di dalamnya. Store layout akan mengundang masuk atau menyebabkan konsumen menjauhi toko tersebut ketika konsumen tersebut melihat bagian dalam toko melalui jendela etalase atau pintu masuk. Aspek yang termasuk store layout meliputi elemen-elemen, diantaranya yaitu:

a. Alokasi lantai ruangan, dalam suatu toko ruangan yang ada harus dialokasikan.

b. Pengelompokan produk.

c. Traffic low (pola arus lalu lintas).

4. Interior Display (Pengaturan Informasi)

Interior display (pengaturan informasi) merupakan tanda-tanda yang digunakan untuk memberikan informasi kepada konsumen untuk mempengaruhi suasa lingkungan toko, dengan tujuan utama untuk meningkatkan penjualan dan laba toko tersebut, yang termasuk interior display terdiri dari:

a. Assortment display

b. Theme-setting display 
c. Ensamble display

Posters, signs, and cards display

\section{Lokasi}

Lokasi usaha dapat juga disebut dengan saluran distribusi perusahaan karena lokasi tersebut juga berhubungan langsung dengan pembelian atau dengan kata lain lokasi juga merupakan tempat produsen menyalurkan produknya kepada konsumen.

Menurut Ratih Hurriyati (2015:56) dikatakan bahwa Tempat (place) diartikan sebagai tempat pelayanan jasa, berhubungan dengan dimana perusahaan harus bermarkas dan melakukan operasi atau kegiatannya. Teori lain mengenai lokasi menurut Fandy Tjiptono (2015:354) yaitu lokasi mengacu pada berbagai aktivitas pemasaran yang berusaha memperlancar dan mempermudah penyampaian atau penyaluran barang dan jasa dari produsen kepada konsumen. Definisi lokasi menurut Kotler dan Amstrong (2018:158) "Locations is various activities of the company to make products produced or sold affordable and available to the target market".

Pendapat mengenai lokasi dari para ahli tersebut bahwa lokasi adalah suatu keputusan perusahaan untuk menentukan tempat usaha, menjalankan kegiatan usaha, dan mendistribusikan barang atau jasa yang menjadi kegiatan bisnisnya kepada konsumen. Pentingnya lokasi bagi perusahaan atau pengusaha sangat mempengaruhi konsumen dan akhirnya akan memutuskan keputusan konsumen dalam memilih pasar sasarannya dalam menentukan keputusan pembeliannya.

Pertimbangan dalam pemilihan lokasi menjadi suatu hal yang penting dalam suatu perusahaan, sebab pemilihan lingkungan lokasi yang baik dapat memberikan kenyamanan dan kemudahan bagi konsumen untuk berkunjung ke tempat perusahaan berada.

Menurut Fandy Tjiptono (dalam Kuswatiningsih, 2016:15) yaitu sebagai berikut :

1. Akses, misalnya lokasi yang sering dilalui atau mudah untuk dijangkau sarana transportasi.

2. Visibilitas, yaitu lokasi atau tempat yang dapat dilihat dengan jelas dari jarak pandang normal.

3. Lalu lintas (traffic) menyangkut dua pertimbangan utama yaitu:

a. Banyaknya orang yang lalu-lalang bisa memberikan peluang besar terhadap pembelian, yaitu keputusan pembelian yang sering terjadi sepontan, tanpa perencanaan, dan atau tanpa melalui usaha-usaha khusus.

b. Kepadatan dan kemacetan lalu lintas bisa jadi peluang.

4. Tempat parkir yang luas, nyaman, dan aman baik untuk kendaraan roda dua maupun roda empat.

5. Ekspansi, yaitu tersedianya lahan yang cukup luas apabila perusahaan memiliki rencana untu melakukan perluasan perusahaan dikemudian hari.

6. Lingkungan, yaitu daerah sekitar yang mendukung produk yang ditawarkan. Sebagi contoh, restoran atau rumah makan berdekatan dengan daerah pondokan, asrama, kampus, sekolah, perkantoran, dan lainnya.

7. Persaingan (lokasi persaingan), sebagai contoh, dalam menentukan lokasi restoran perlu dipertimbangkan apakah di jalan atau daerah yang sama terdapat restoran lainnya atau terdapat usaha yang sejenis.

8. Peraturan pemerintah, misalnya ketentuan yang melarang rumah makan berlokasi terlalu berdekatan dengan pemukiman penduduk atau tempat ibadah, karena takut dapat mengganggu kenyaman masyarakat sekitar.

\section{Media Sosial}

Berkembangnya teknologi yang semakin maju membuat media promosi dalam perusahaan semakin bertambah salah satunya menggunakan media internet.

Terence A. Shimp yang dialih bahasakan oleh Harya, dkk (2014:165) menjelaskan bahwa, "Media sosial sebagai konvergensi antara komuniskasi personal dalam arti saling berbagi di antara individu (to be shared on-one-to-one) dan media publik untuk berbagi 
kepada siapa saja tanpa ada kekhususan individu". Sedangkan menurut penjelasan Kotler dan Keller (2016:642) mengatakan bahwa "Social media are a means for consumers to share text, image, audio, and video information with each other and with companies, and vice versa". Bebeda halnya dengan pendapat Rulli Nasrullah (2017:4) yang mendefinisikan, "Media sosial adalah medium internet yang memungkinkan pengguna mempresentasikan dirinya maupun berinteraksi, bekerjasama, berbagi komunikasi dengan pengguna lain, dan membentuk ikatan sosial secara virtual".

Berdasarkan beberapa definisi di atas menunjukan bahwa dalam media sosial merupakan sarana pertukaran informasi yang mewadahi kerjasama antara individu untuk saling berbagi antar individu dan dapat digunakan juga sebagai sarana promosi perusahaan dengan membentuk ikatan sosial secara virtual, dengan memberikan promosi melalui gambar, suara, dan video.

Media sosial mempunyai beberapa dimensi yang saling mempengaruhi satu sama lain, menurut Phillip Kotler dan Kevin Keller (2016:64), yaitu:

1. Social presence

Social presence dapat diartikan dengan kontak yang terjadi ketika terjadi proses komunikasi penilalian responden atas dimensi social presence yaitu interaksi media sosial.

2. Media Richnes

Media richnes dapat diartikan dengan mengurangi ketidakjelasan dan ketidaknyamanan informasi melalui proses komunikasi.

3. Self disclosure

Dimensi ini diartikan sebagai mengembangkan hubungan dekat dengan melalui pengungkapan diri seperti perasaan, suka, tidak suka, dan pemikiran. Melalui media sosial konsumen dapat mengutarakan pengungkapannya.

\section{Keputusan Pembelian}

Keputusan konsumen dalam melakukan pembelian suatu produk merupakan suatu tindakan yang lazim dijalani oleh setiap individu konsumen ketika mengambil keputusan pembelian. Keputusan konsumen untuk melakukan pembelian atau tidak melakukan pembelian merupakan bagian dari unsur yang melekat pada diri individu konsumen yang disebut sebagai perilaku dimana lebih merujuk kepada fisik yang nyata.

Definisi keputusan pembelian menurut Buchari Alma (2014:96) yaitu keputusan pembelian sebagai suatu keputusan konsumen yang dipengaruhi oleh ekonomi keuangan, teknologi, politik, budaya, produk, harga, lokasi, promosi, pyhsical evidence, people, process, sehingga membentuk suatu sikap pada konsumen untuk mengolah segala informasi dan mengambil kesimpulan berupa respons yang muncul produk apa yang akan dibeli. Teori lain dari Kotler \& Keller (2016:192): "In the evaluation stage, the consumer ranks brands and forms purchase intentions. Generally, the consumer's purchase decision will be to buy the most preferred brand, but two factors can come between the purchase intention and the purchase decision". Sama halnya menurut Kotler dan Armstrong (2018:102) "In the evaluation stage, the consumer forms preferences among the brands in the choice set and may also form an intention to buy the most preferred brand".

Berdasarkan beberapa pengertian di atas dapat disimpulkan bahwa keputusan pembelian adalah proses memilih satu dari berbagai pilihan yang terdiri dari dua atau lebih pilihan alternatif yang ada dan sesuai dengan kepentingan-kepentingan yang telah dipertimbangkan keuntungan dan kekurangan dari pilihan-pilihan alternatif.

Dimensi keputusan pembelian konsumen, terdapat enam sub keputusan yang dilakukan oleh pembeli yaitu menurut Kotler \& Keller (2016:195), diantaranya:

1. Product Choice (Pilihan Produk)

Konsumen dapat mengambil keputusan untuk membeli sebuah produk atau menggunakan uangnya untuk tujuan yang lain. Dalam hal ini perusahaan harus memusatkan perhatiannya kepada orang-orang yang berminat membeli sebuah produk serta alternatif yang mereka pertimbangkan. 
2. Brand Choice (Pilihan Merek).

Konsumen harus mengambil keputusan tentang merek mana yang akan dibeli. Setiap merek memiliki perbedaan-perbedaan tersendiri. Dalam hal ini perusahaan harus mengetahui bagaimana konsumen memilih sebuah merek yang terpercaya.

3. Dealer Choice (Pilihan Tempat Penyalur).

Konsumen harus mengambil keputusan tentang penyalur mana yang akan dikunjungi. Setiap konsumen berbeda-beda dalam hal menentukan penyalur bisa dikarenakan faktor lokasi yang dekat, harga yang murah, persediaan barang yang lengkap, kenyamanan berbelanja, keluasan tempat dan lain sebagainya.

4. Purchase Amount (Jumlah Pembelian atau Kuantitas).

Konsumen dapat mengambil keputusan tentang seberapa banyak produk yang akan dibelinya pada suatu saat. Pembelian yang dilakukan mungkin lebih dari satu jenis produk. Dalam hal ini perusahaan harus mempersiapkan banyaknya produk sesuai dengan keinginan yang berbeda-beda dari para pembeli.

5. Purchase Timing (Waktu Pembelian).

Keputusan konsumen dalam pemilihan waktu pembelian bisa berbeda-beda, misalnya : ada yang membeli setiap hari, satu minggu sekali, dua minggu sekali, tiga minggu sekali atau sebulan sekali dan lain-lain.

6. Payment Method (Metode Pembayaran).

Konsumen dapat mengambil keputusan tentang metode pembayaran yang akan dilakukan dalam pengambilan keputusan konsumen produk atau jasa.

Adapun kerangka penelitian yang menyatakan pengaruh variabel $X_{1}, X_{2}, X_{3}$, dan $Y$ secara simultan dan parsial dapat dilihat sebagai berikut:

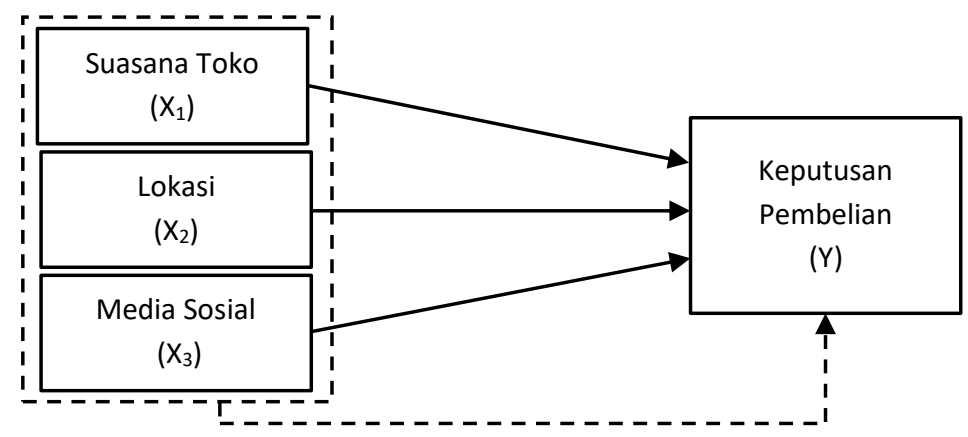

Keterangan:

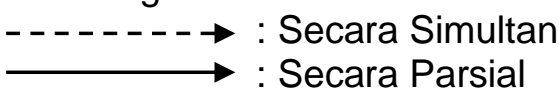

Berdasarkan uraian dari kajian pustaka, dan kerangka pemikiran diatas, maka hipotesis pada penelitian ini yaitu sebagai berikut:

1. Secara Parsial

a. Terdapat pengaruh suasana toko terhadap keputusan pembelian.

b. Terdapat pengaruh lokasi terhadap keputusan pembelian

c. Terdapat pengaruh media sosial terhadap keputusan pembelian

2. Secara Simultan

"Terdapat pengaruh suasana toko, lokasi, dan media sosial terhadap keputusan pembelian".

\section{METODE}

Jenis penelitian yang digunakan dalam penelitian ini yaitu analisis deskriptif dan analisis

verifikatif. Populasi yang dijadikan sebagai penelitian adalah pengunjung Kopi Aenk pada tujuh bulan terakhir sebelum peneliti melakukan penelitian dengan total rata-rata populasi sebanyak 937 orang dan tingkat kesalahan yang dapat ditolerir sebesar $10 \%(0,1)$ atau dapat disebutkan tingkat keakuratan $90 \%$ dan penentuan ukuran sampel tersebut menggunakan 
rumus Slovin, sehingga sampel yang diambil untuk mewakili populasi tersebut sebesar 91 orang responden. Teknik pengumpulan data yang digunakan dalam penelitian ini adalah penelitian lapangan dan penelitian studi kepustakaan, sedangkan untuk pengujian data yang digunakan dalam penelitian ini yaitu validitas dan reliabilitas. Metode analisis yang digunakan adalah analisis regresi linier berganda, analisis korelasi berganda, uji hipotesis, dan analisis koefisien determinasi.

\section{HASIL DAN PEMBAHASAN}

Hasil jawaban responden mengenai variabel suasana toko yang memiliki 9 pernyataan dan menggunakan 4 dimensi, yang memiliki rata-rata jumlah skor sebesar 3,04 dan berada pada rentang skala 2,60-3,40 maka dapat disimpulkan bahwa tanggapan responden mengenai variabel suasana toko berada pada kategori kurang setuju, hal ini menunjukan bahwa suasana toko di Kopi Aenk menurut konsumen kurang nyaman. Beberapa pernyataan yang dibawah rata-rata jumlah skor, antara lain: (1) tingkat kemenarikan pajangan dekorasi ruangan dengan nilai rata-rata sebesar 2,52; (2) tingkat kelengkapan fasilitas dengan nilai rata-rata sebesar 2,60; (3) tingkat keluasan pintu masuk dengan nilai rata-rata sebesar 2,89.

Hasil penelitian deskriptif rekapitulasi tanggapan responden mengenai variabel lokasi dengan menggunakan 7 dimensi dan memiliki 9 pernyataan, yang memiliki rata-rata jumlah skor sebesar 2,79 dalam kategori kurang setuju dan berada pada rentang skala 2,60-3,40, sehingga dapat disimpulkan bahwa lokasi Kopi Aenk kurang strategis. Dimana masih terdapat beberapa pernyataan yang dibawah rata-rata jumlah skor, diantaranya: (1) lahan parkir cafe luas dengan nilai rata-rata sebesar 2,01; (2) lalu lintas disekitar cafe lancar dengan nilai ratarata sebesar 2,34; (3) tingkat kejelasan lokasi dengan nilai rata-rata sebesar 2,52.

Hasil jawaban responden mengenai variabel media sosial yang memiliki 6 pernyataan dan menggunakan 3 dimensi, yang memiliki rata-rata jumlah skor sebesar 3,03 berada pada kategori kurang sutuju dan pada garis kontinum berada pada rentang skala 2,60-3,40, sehingga dapat disimpulkan bahwa media sosial yang di pakai Kopi Aenk kurang menarik. Beberapa pernyataan yang dibawah rata-rata jumlah skor, antara lain: (1) media sosial yang diberikan dapat menambah keyakinan terhadap informasi yang disampaikan, dengan nilai rata-rata sebesar 2,46; (2) media sosial dapat memudahkan dalam mendapatkan informasi, dengan nilai rata-rata sebesar 2,61; (3) media sosial dapat mewakili dalam berinteraksi promosi di Kopi Aenk, dengan nilai rata-rata sebesar 2,69.

Variabel keputusan pembelian berdasarkan hasil jawaban responden dengan 6 dimensi, yang memiliki rata-rata jumlah skor sebesar 3,11 berada pada kategori kurang setuju dan pada garis kontinum berada pada rentang skala 2,60-3,40, hal ini menunjukan bahwa keputusan pembelian yang diterapkan Kopi Aenk masih kurang baik. Disebabkan oleh adanya beberapa indikator yang masih dibawah rata-rata jumlah skor, diantaranya; (1) sering melakukan pembelian produk di Kopi Aenk, sebesar 2,69; (2) tidak pernah mengalami ketidaktersediaan produk di Kopi Aenk, sebesar 3,00; (3) pembelian produk di Kopi Aenk karena popularitas mereknya, sebesar 3,73.

\section{Uji Hipotesis Simultan}

\begin{tabular}{|c|c|c|c|c|c|c|}
\hline \multicolumn{7}{|c|}{ ANOVA $^{a}$} \\
\hline & & Sum of Squares & $d f$ & Mean Square & $\mathrm{F}$ & Sig \\
\hline \multirow{3}{*}{1} & Regression & 2392,915 & 3 & 797,638 & 247,577 &, $000^{\mathrm{b}}$ \\
\hline & Residual & 280,295 & 87 & 3,222 & & \\
\hline & Total & 2673,210 & 90 & & & \\
\hline
\end{tabular}

a. Dependent Variable: Keputusan Pembelian

b. Predictors: (Constant), Media Sosial, Suasana Toko, Lokasi

Sumber: Hasil Pengolahan Data SPSS 20.0

Berdasarkan tabel tersebut dapat dilihat hasil pengolahan $\mathrm{F}$ hitung diperoleh sebesar 247,577. Pada uji F untuk tingkat signifikasi 0,05 atau 5\% dan derajat bebas $(n-3-1)=91-3-1$ 
$=87$. Diperoleh $\mathrm{F}$ Tabel $=2,71$, karena $\mathrm{F}$ hitung $>\mathrm{F}$ Tabel 247,577 $>2,71$, dan sig $\mathrm{F}$ sebesar 0,000 maka dapat diambil keputusan untuk menolak $\mathrm{H}_{0}$ dan $\mathrm{H}_{1}$ diterima. Artinya terdapat pengaruh yang signifikan dari suasana toko, lokasi, dan media sosial terhadap keputusan pembelian pada Kopi Aenk.

Berdasarkan hasil uji hipotesis parsial dalam pengolahan data dapat dilakukan pengujian hipotesis dengan nilai hitung sebagai berikut:

a. Jika $t_{\text {hitung }}>t_{\text {tabel }}$ maka $\mathrm{H}_{0}$ ditolak

b. Jika $t_{\text {hitung }}<\mathrm{t}_{\text {tabel }}$ maka $\mathrm{H}_{1}$ diterima

Untuk mengetahui jika tabel maka perhitungan didasarkan pada derajat kebebasan $\mathrm{df}=\mathrm{n}$ k-I yakni 91-3-1 = 87 dengan taraf signifikan 0,05 atau 5\% diperoleh dari $t_{\text {tabel }}=1,66256$. Dapat dilihat dari pengolahan data dengan kriteria penolakan $\mathrm{H}_{0}$, jika $t_{\text {hitung }}>\mathrm{t}_{\text {tabel }}$.

1. Variabel suasana toko (X1) diperoleh thitung 6,253 dengan taraf signifikan 0,000 maka tabel $=1,66256$, sehingga dikarenakan thitung $=6,253>1,66256$ atau 6,253 lebih besar dari 1,66256 maka $\mathrm{H}_{0}$ ditolah dan $\mathrm{H}_{1}$ diterima. Artinya suasana toko berpengaruh signifikan terhadap keputusan pembelian pada Kopi Aenk.

2. Variabel lokasi (X2) diperoleh thitung 3,255 dengan taraf signifikan 0,002 maka $t_{\text {tabel }}=$ 1,66256, sehingga dikarenakan thitung $=3,255>1,66256$ atau 3,255 lebih besar dari 1,66256 maka $\mathrm{H}_{0}$ ditolak dan $\mathrm{H}_{1}$ diterima. Artinya lokasi berpengaruh signifikan terhadap keputusan pembelian pada Kopi Aenk.

3. Variabel media sosial (X3) diperoleh $t_{\text {hitung }} 3,801$ dengan taraf signifikan 0,000 maka $t_{\text {tabel }}=$ 1,66256, sehingga dikarenakan $t_{\text {hitung }}=3,801>1,66256$ atau 3,801 lebih besar dari 1,66256 maka $\mathrm{H}_{0}$ ditolak dan $\mathrm{H}_{1}$ diterima. Artinya media sosial berpengaruh signifikan terhadap keputusan pembelian pada Kopi Aenk.

Pengaruh secara simultan suasana toko, lokasi, dan media sosial terhadap keputusan pembelian yaitu sebagai berikut:

Model Summary ${ }^{b}$

\begin{tabular}{ccccc}
\hline Model & $\mathrm{R}$ & R Square & $\begin{array}{c}\text { Adjusted } \mathrm{R} \\
\text { Square }\end{array}$ & $\begin{array}{c}\text { Std. Error of the } \\
\text { Estimate }\end{array}$ \\
\hline 1 &, $946^{\mathrm{a}}$ &, 895 &, 892 & 1,79493 \\
\hline
\end{tabular}

a. Predictors: (Constant), Media Sosial, Suasana Toko, Lokasi

Sumber: Hasil Pengolahan Data SPSS 20.0

Dapat dilihat bahwa nilai koefisien determinasi secara simultan sebesar 0,895. Nilai tersebut mengindikasikan bahwa secara simultan suasana toko, lokasi, dan media sosial berpengaruh terhadap keputusan pembelian sebesar $89,5 \%$, sedangkan sisanya $(100 \%-89,5 \%=10,5 \%)$ dipengaruhi oleh variabel independen lainnya yang tidak diteliti.

Coefficients $^{\mathrm{a}}$

\begin{tabular}{lccc}
\hline Model & $\begin{array}{c}\text { Unstandardized } \\
\text { Coefficients }\end{array}$ & $\begin{array}{c}\text { Standardized } \\
\text { Coefficients }\end{array}$ & Correlations \\
\cline { 2 - 4 } & $\mathrm{B}$ & Beta & Zero-order \\
\hline (Constant) & 1,737 & &, 914 \\
Suasana Toko &, 460 &, 467 &, 901 \\
Lokasi &, 257 &, 273 &, 865 \\
\hline Media Sosial &, 376 &, 257 & \\
\hline
\end{tabular}

a. Dependent Variable: Keputusan Pembelian

Sumber: Hasil Pengolahan Data SPSS 20.0

Berdasarkan hasil perhitungan besarnya pengaruh masing-masing variabel independent (suasana toko, lokasi, dan media sosial) terhadap variabel dependent (keputusan pembelian) dapat diketahui bahwa besarnya pengaruh suasana toko (X1) terhadap keputusan pembelian (Y) sebesar 42,7\%, sedangkan besarnya pengaruh lokasi (X2) terhadap keputusan pembelian (Y) sebesar $24,6 \%$, besarnya pengaruh media sosial (X3) terhadap keputusan pembelian (Y) sebesar $22,2 \%$, dan sisanya sebesar $10,5 \%$ di pengaruhi oleh variabel independent lainnya yang tidak diteliti dalam penelitian ini. 


\section{KESIMPULAN}

Berdasarkan hasil pembahasan yang telah diuraikan mengenai pengaruh suasana toko, lokasi, dan media sosial terhadap keputusan pembelian, maka dapat diambil kesimpulan sebagai berikut:

1. Tanggapan responden terkait variabel suasana toko yang diberikan Kopi Aenk termasuk pada kategori kurang setuju, hal ini menunjukan bahwa menurut konsumen suasan toko di Kopi Aenk kurang nyaman. Peneliti menemukan masih adanya beberapa indikator yang memperoleh nilai dibawah rata-rata jumlah skor suasana toko, antara lain yaitu kemenarikan pajangan dekorasi cafe, cafe memiliki fasilitas tambahan yang memadai, dan pintu masuk cafe.

2. Tanggapan responden terkait variabel lokasi yang diberikan Kopi Aenk termasuk pada kategori kurang setuju, hal ini menunjukan bahwa menurut konsumen lokasi Kopi Aenk kurang strategis. Peneliti menemukan masih adanya beberapa indikator yang memperoleh nilai dibawah rata-rata jumlah skor lokasi, antara lain yaitu indikator lahan parkir cafe luas, lalu lintas disekitar cafe lancar, dan kejelasan lokasi cafe sangat mudah dilihat.

3. Tanggapan responden terkait variabel media sosial yang dipakai di Kopi Aenk termasuk pada kategori kurang setuju, hal ini menunjukan bahwa menurut konsumen promosi melalui media sosial yang digunakan Kopi Aenk kurang menarik. Peneliti menemukan masih adanya beberapa indikator dibawah rata-rata jumlah skor media sosial, antara lain yaitu keyakinan terhadap informasi yang disampaikan, kemudahkan dalam mendapatkan informasi, dan interaksi media sosial cafe dengan konsumen.

4. Tanggapan reesponden terkait variabel keputusan pembelian yang diberikan Kopi Aenk termasuk pada kategori kurang setuju, hal ini menunjukan bahwa keputusan pembelian konsumen pada Kopi Aenk kurang baik. Peneliti menemukan masih adanya beberapa indikator yang memperoleh nilai dibawah rata-rata jumlah skor keputusan pembelian, antara lain waktu pembelian produk, ketidaktersediaan produk, dan kepopularitas cafe.

5. Semakin baik suasana toko yang diterapkan akan semakin meningkat keputusan pembelian. Suasana toko secara parsial berpengaruh terhadap keputusan pembelian. Besarnya pengaruh variabel suasana toko terhadap keputusan pembelian sebesar $42,7 \%$.

6. Semakin strategis lokasi café akan semakin meningkat keputusan pembelian. Lokasi secara parsial berpengaruh terhadap keputusan pembelian. Besarnya pengaruh variabel lokasi terhadap keputusan pembelian sebesar $24,6 \%$.

7. Semakin baik pemakaian media sosial untuk promosi akan meningkatkan keputusan pembelian. Media sosial secara parsial berpengaruh terhadap keputusan pembelian. Besarnya pengaruh variabel media sosial terhadap keputusan pembelian sebesar $22,2 \%$.

8. Ada hubungan yang sangat kuat antara suasana toko, lokasi, dan media sosial dengan keputusan pembelian. Secara simultan suasana toko, lokasi, dan media sosial memberikan pengaruh yang signifikan terhadap keputusan pembelian. Suanana toko, lokasi, dan media sosial memberikan pengaruh sebesar $89,5 \%$ terhadap keputusan pembelian.

\section{DAFTAR PUSTAKA}

A. Shimp, Terence. 2014. Komunikasi Pemasaran Terpadu dalam Periklanan dan Promosi. Edisi 8, Alih Bahasa: Harya Bhima dkk. Salemba Empat, Jakarta.

Berry Berman dan Joel R. Evans. 2014. Retail Management. 12 th Edition. Dialih bahasakan oleh Lina Salim. Pearson, Jakarta.

Buchari Alma. 2014. Manajemen Pemasaran dan Pemasaran Jasa. Alfabeta, Bandung. Fandy Tjiptono. 2015. Pemasaran Jasa. Gramedia Cawang, Jakarta.

Kotler, Phillip dan Gary Amstrong. 2018. Principles of Marketing. 17 th Edition Pearson.

Kotler, Phillip dan Kevin L. Keller. 2016. Markeing Management. 15 th Edition. Pearson Prentice Hall, New Jersey.

Levy dan Weitz. 2014. Retailing Management. 7 th Edition. The McGraw-Hill Companies.Inc, New York. 
Oikos: Jurnal Kajian Pendidikan Ekonomi dan IImu Ekonomi, ISSN Online: 2549-2284

Volume IV Nomor 1, Januari 2020

Ratih Hurriyati. 2015. Bauran Pemasaran dan Loyaritas Konsumen. Alfabetha, Bandung. Rulli Nasrullah. 2017. Media Sosial. Simbiosa Rekatama Media, Bandung.

Sugiyono. 2017. Metodologi Peneitian Kuntitatif, Kualitatif, dan R\&D. CV Alfabeta, Bandung. 